\title{
Foods advertised in US weekly supermarket sales circulars over one year: a content analysis
}

\author{
Lisa Jahns ${ }^{1 *}$, Collin R Payne ${ }^{2}$, Leah D Whigham ${ }^{3}$, LuAnn K Johnson ${ }^{1}$, Angela J Scheett ${ }^{1}$, Bonita S Hoverson ${ }^{1}$ \\ and Sibylle Kranz ${ }^{4}$
}

\begin{abstract}
Background: The nutritional content of Americans' shopping carts is suboptimal despite federal dietary guidance, in this case, the MyPlate consumer icon which displays desired proportions of vegetables, fruits, dairy, grains and protein foods for consumption. Consumers mention print advertising — such as weekly sales circulars—-frequently as influencing their grocery shopping decisions.

Methods: To examine and describe the relative proportions of advertised foods aggregated into the MyPlate food grouping system, a content analysis of 9209 foods advertised in 52 weekly supermarket newspaper sales inserts in 2009 from a local grocery chain was conducted in a Midwestern community.

Results: Overall, the protein foods group was most often represented in sales circulars ( $25 \%$ of total items), followed by grains (18\%); dairy (10\%); vegetables (8\%) and fruits (7\%). Less than $3 \%$ of sales advertisements were for dark green and red \& orange vegetables. Over twice as much whole fruit versus 100\% fruit juice was advertised ( $70 \%$ vs. $30 \%$, respectively; $P<0.001$ ). Significantly fewer protein foods and more grains than expected were advertised in the fall, and slightly more dark green vegetables were advertised in winter and spring than in summer and fall $(P=0.05)$.

Conclusions: The average American diet, including underconsumption of fruits and vegetables but overconsumption of protein foods, was reflected in the relative frequency of food groups advertised in weekly sales circulars. Modifying sales circulars to represent healthier food groups may preserve retail profits (considering these groups' higher profit margin) while promoting adherence to federal dietary guidance.
\end{abstract}

Keywords: Dietary guidelines, Advertising, Supermarkets, Grocery stores, Promotion

\section{Background}

Americans reported spending an average of $\sim \$ 400.00$ USD each month at supermarkets in 2012, and spending has increased slightly since 2006 [1]. While some of the monthly expenditure can be explained by consumer demand for specific food items (e.g., organic products), more can be explained by supermarket strategies to promote specific products that maximize store profitability $[2,3]$. One very effective way supermarkets promote specific products is through weekly sales circulars, both in print and online.

\footnotetext{
* Correspondence: lisa.jahns@ars.usda.gov

'United States Department of Agriculture, Agricultural Research Service, Grand Forks Human Nutrition Research Center, Grand Forks, ND 58203, USA Full list of author information is available at the end of the article
}

Weekly sales circulars provide information to consumers about not only price discounts, but also what foods to consider purchasing. Price discount information is important considering economic downturns and rising food prices [1,4-8]. Indeed, $88 \%$ of consumers say that price is somewhat or very important when buying food [9]. Information regarding what foods to purchase is important considering consumers have to contend with multiple possible grocery stores in which to shop and an average of 39000 items from which to choose within each store [10]. Weekly grocery store sales circulars help facilitate food purchasing decisions [11].

Over 70\% percent of US adults read newspaper circulars $[11,12]$. Half of shoppers report using technology when grocery shopping and $23 \%$ of these shoppers report that they check prices at multiple stores before shopping 
[1]. Circulars have been shown to increase targeted versus untargeted item purchasing by $100 \%$ [13]. In fact, supermarket sales circulars are so effective in stimulating demand [13-16] that it is difficult to find a supermarket that does not use them.

Considering weekly sales circulars' effectiveness on influencing consumer purchases, it is not surprising that seasonal changes in promotion would affect consumer purchase types and amounts. For example, there is evidence that food pricing and advertising vary seasonally [17], as do purchases of vegetables and fruits [18]. Furthermore, seasonality may be associated with food intake [19-21], suggesting that advertising different foods more heavily at certain times of the year, such as vegetables and fruits in the summer or meats over holidays, may influence demand. Despite being an important new area of research given the influence of advertising on purchasing and its potential to positively impact dietary habits, the healthfulness of food items advertised in sales circulars is understudied. To our knowledge, there have been only two short-term studies published to date $[22,23]$ that have described the contents of weekly grocery store sales circulars. Examination of supermarket sales circular content is critical to diet quality research to help understand commercial promotion of food types, which-inadvertently or advertently-are used as consumption recommendations [24]. Given that American's food purchases [25] and dietary intake [26] fall short of the Dietary Guidelines for Americans (DGA) [27] recommendations, and that supermarket sales circulars are widely used by consumers to guide their purchases, circulars have the potential to have a positive influence on an individual's diet quality [24].

Accordingly, the goal of this study was to examine the content of a year's worth of sales circulars to determine whether food groups advertised in sales circulars varied from recommended food group intake guidance overall and by season. We hypothesized that circulars would reflect seasonal changes and advertise more vegetables and fruits in summer and fall compared to the winter and spring seasons.

\section{Methods}

Fifty-two weekly supermarket sales circulars dating from January 1 to December 31, 2009 were collected from a local Midwestern supermarket chain. The chain consists of eight stores located in a city of 69000 predominantly Non-Hispanic white individuals (86.7\%) [28], and is considered small compared to other chain supermarkets [29]. As all stores belonged to the same chain, there was no variation in the circulars by individual store. Each food item in the weekly circulars was dual-coded by trained research personnel to assure data entry accuracy; all discrepancies were resolved by a supervisory research dietitian. A total of 9209 food items were coded. The coding scheme for the advertised items was as follows: all items advertised in the circulars were classified as food or nonfood items. Food items were further classified into food groups and subgroups of food groups. Guidelines for classifying were based upon the following: The initial groupings were based on the Food Group Description File from the USDA National Nutrient Database for Standard Reference, Release 22 [30] and subgroups from USDA Handbook 8 (AH8) [31] with minor modifications to include products not originally designated in AH8. Food items were then grouped by major food groups (vegetables, fruits, grains, protein foods, and dairy) and subgroups of MyPlate, the consumer icon implementing the DGA [32] ( $n=6366 ; 69 \%)$ using the MyPyramid Equivalents Database [33]. The DGA makes recommendations to limit or reduce intake of the food components termed empty calories (solid fats and added sugars), therefore this group was also included. The solid fats group contains fats that are solid at room temperature, such as margarine spreads and added sugars refers to sugar that is not naturally-occurring and is added to foods during processing. The added sugars group in this study includes foods that are comprised predominantly of added sugar, such as sugar-sweetened beverages and hard candy [32]. Advertised items that did not have enough detail to determine the food group were categorized as "other" $(\mathrm{n}=2$ 843). The "other" group included mixed dishes that could not be categorized into food groups. Wherever possible, the major food groups were disaggregated into subgroups. For instance, the fruit group was divided into whole fruit and $100 \%$ fruit juice, and dairy, protein, and vegetable groups were broken into individual components. It was not possible to identify whole versus non-whole grain products from the advertisements, however, we subjectively categorized grain products as "with" or "without" added sugars. For instance, cakes, cookies, and sweet rolls were categorized as "with added sugar" while bread, pasta, and crackers were classified "without added sugar". Seasons were categorized using the meteorological definition as follows: winter (December, January, February), spring (March, April, May), summer (June, July, August), and fall (September, October, November).

To determine whether observed frequencies of the five recommended food groups in the advertisements $(n=6$ 366) varied significantly from what was expected across seasons, a contingency table analysis was conducted using PASW Statistics 18, Release Version 18.0 [34]. Significant discrepancies between observed versus expected frequencies were determined by computing adjusted chi-square residuals for each contingency table cell. As adjusted chisquare residuals are normally distributed, any residual value greater than or equal to \pm 1.96 is interpreted as a significant departure from what was expected [35]. 
A generalized linear model was used to test for seasonal differences in the relative proportions of advertised items for each food group and subgroup using Proc GENMOD in SAS Version 9.2 [36]. If the overall model was significant, Tukey's contrasts were used to do pairwise comparisons between all seasons.

\section{Results}

The proportions of all food and subgroups advertised over the year are presented in Figures 1 and 2. Over the year, the groups frequently advertised of the recommended food groups was the protein foods group, which comprised one-fourth of all items described. Grains were the next most often advertised group (18\%), followed by dairy $(10 \%)$, vegetables $(8 \%)$, and fruits $(7 \%)$. Sixteen percent of foods were categorized as empty calories while another $14 \%$ were not able to be categorized. Meat, poultry and cheese were the most often advertised items in the protein and dairy groups, respectively.

Sixty-nine percent of all food items were categorized into the five major food groups. The frequency of items advertised approached significance as a function of season (overall chi-square test of independence, $X^{2}(12$, $N=6,316)=20.1, P=0.066$ ). The adjusted chi-square residuals are plotted in Figure 3. Advertised frequencies of grains were significantly higher in fall $(z=2.97, P=0.003)$ and lower than expected in the spring $(z=1.95, P=0.051)$. The frequency of protein foods advertised was lower than expected in fall $(z=2.62, P<0.009)$. There were

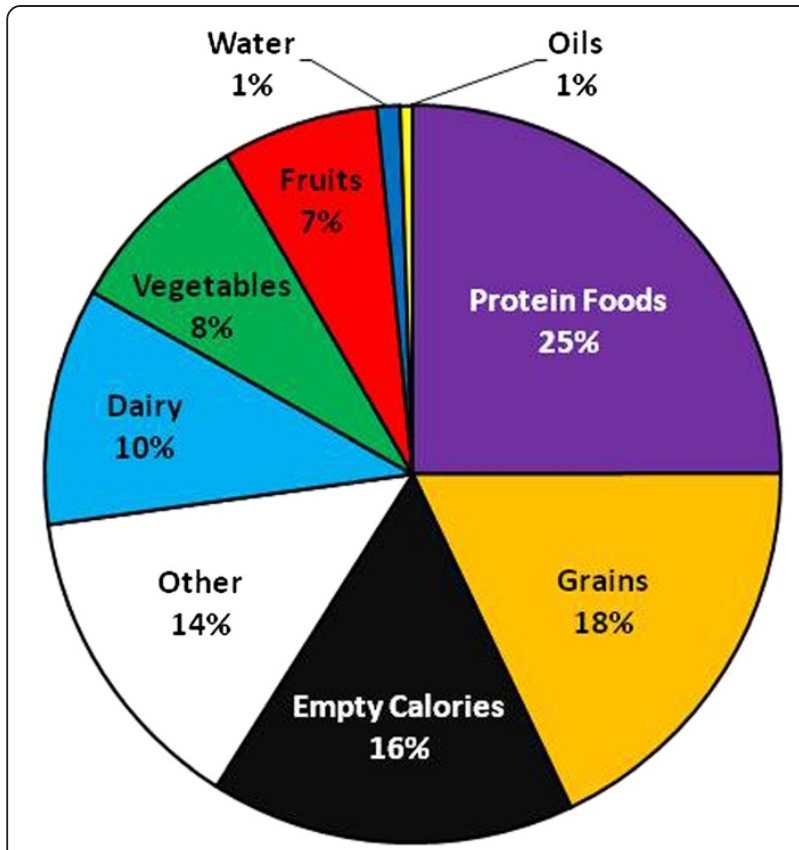

Figure 1 Proportions of food groups advertised in 52 weekly US supermarket sales circulars in 2009. no significant differences in the observed frequencies in the vegetable, fruit, or dairy groups by season.

Next, we examined differences in groups and subgroups by season using generalized linear regression (Table 1). Items in the grain group were advertised significantly more often in fall compared to spring or summer $(P<0.001)$ and grains without added sugar was lowest in the spring months $(P<0.001)$. There were no seasonal differences in frequency of advertisments of grains with added sugar. Overall, there were no significant differences in the dairy group $(P=0.35)$, but fluid milk advertisements varied seasonally $(P=0.02)$. Advertised dark green vegetables also varied by season $(P=0.05)$; as did seafood, which was more heavily advertised in the winter months $(P<0.001)$.

\section{Discussion}

In this study we described the seasonal content of one year's worth of Sunday supermarket circulars. There was little variation between the frequencies of food groups advertised by season. In particular, advertisements for the major fruit and vegetable groups did not vary significantly during the summer or fall seasons, as one would expect, since one might assume that they are more easily available to supermarkets during the harvest months of the year. Only the promotion of dark green vegetables varied by season, with the highest numbers in spring compared to summer, although the absolute number of items advertised was neligible. However, advertisements for grains were greater in the fall and lower in spring whilst the frequency of protein foods was lower in the fall season than expected. The increased advertising of grain products in the fall was not due to changes in the grains with added sugar category, as might be anticipated with the demand for holiday baked goods, such as cookies and other sweetened desserts, but due to changes in the grains without added sugar category.

Overall, the frequency of advertisements for most food groups by this supermarket chain did not reflect current recommendations. Although nearly $50 \%$ of the recommended foods by the DGA are fruits and vegetables, we found that only a small proportion of advertisements were for items from those two food groups (15\%). Encouragingly, one-fifth of items advertised were grain products. Although we were unable to distinguish whole grain items from refined items, we roughly categorized grains with added sugar and grains without added sugar, and found that over half of all grain products advertised were in the without added sugar category. As many food manufacturers are reformulating their grain products to contain more whole grains, the relatively high frequency of advertisements for grain products without added sugar has the potential to increase whole grain purchases and consumption [37]. 


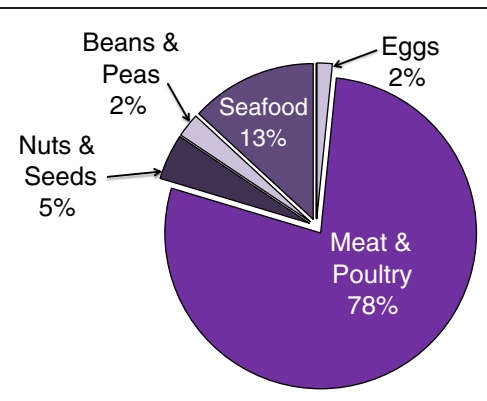

Protein Foods

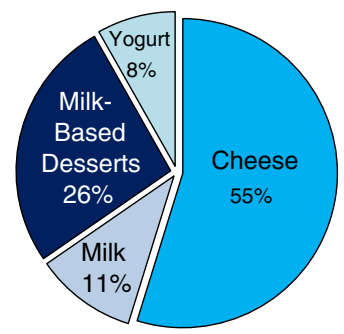

Dairy

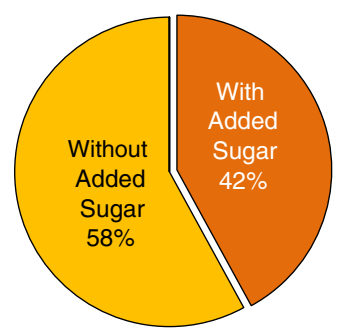

Grains

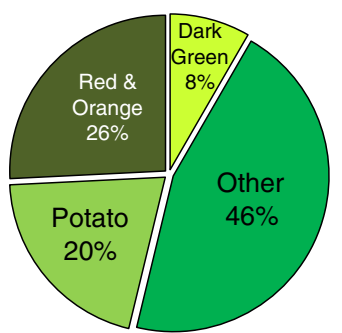

Vegetables

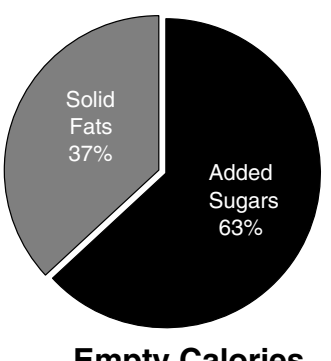

Empty Calories

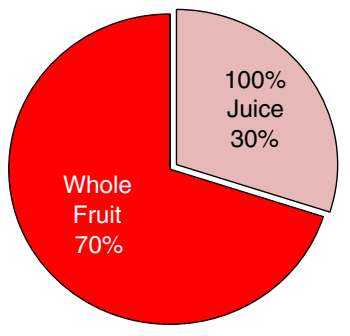

Fruits

Figure 2 Proportions of food subgroups advertised in 52 weekly US supermarket sales circulars in 2009.

Our findings are similar to those of Martin-Biggers et al. [22], who to our knowledge were the first investigators to compare the content of supermarket flyers to dietary recommendations and obesity prevalence in a national sample of sales circulars. Their approach compared the physical space devoted to the major food groups recommended by the DGA on the front page of single weekly supermarket sales circulars nationwide to the space allocated on the MyPlate icon. Despite the fact that their approach differed significantly from ours and they did not examine advertisements over time, they also found that while protein foods were over-represented, dairy, fruits, and vegetables were underrepresented; only the grains group was represented in approximately the same proportions as those shown in the MyPlate icon. It is of interest that the same pattern was found both when

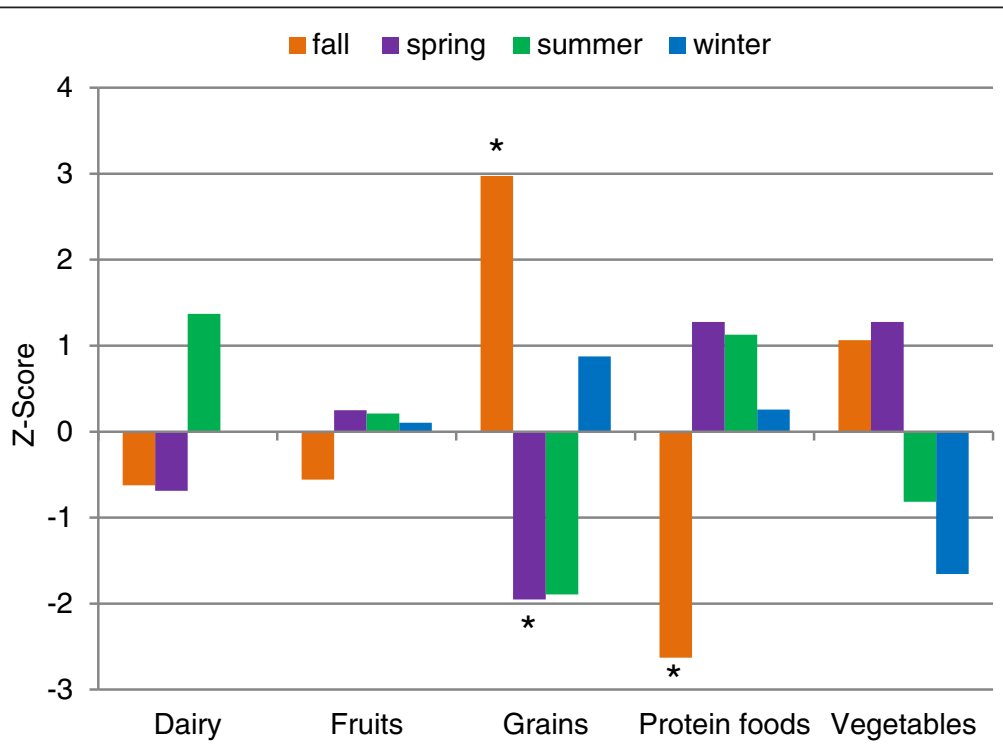

Figure 3 Expected compared to observed frequency of food groups advertised seasonally. Footnotes: Adjusted chi-square residuals were computed for each contingency table cell. Any residual value greater than or equal to \pm 1.96 is interpreted as a significant departure from what was expected in each season and marked with an *. 
Table 1 Differences in the proportions of food groups advertised in weekly supermarket sales circulars by season ${ }^{1}$

\begin{tabular}{|c|c|c|c|c|c|c|c|c|c|}
\hline \multirow{4}{*}{$\begin{array}{l}\text { MyPlate major food groups } \\
\text { and subgroups }\end{array}$} & \multicolumn{8}{|c|}{ Season } & \multirow{4}{*}{$p$-value } \\
\hline & \multirow{2}{*}{\multicolumn{2}{|c|}{$\begin{array}{c}\text { Winter } \\
n=2006\end{array}$}} & \multirow{2}{*}{\multicolumn{2}{|c|}{$\begin{array}{c}\text { Spring } \\
n=2622\end{array}$}} & \multirow{2}{*}{\multicolumn{2}{|c|}{$\begin{array}{l}\text { Summer } \\
n=2154\end{array}$}} & \multirow{2}{*}{\multicolumn{2}{|c|}{$\begin{array}{c}\text { Fall } \\
n=2427\end{array}$}} & \\
\hline & & & & & & & & & \\
\hline & $\mathrm{n}$ & $\%$ & $\mathrm{n}$ & $\%$ & $\mathrm{n}$ & $\%$ & $\mathrm{n}$ & $\%$ & \\
\hline Grains & 388 & $19.3^{\mathrm{ac}}$ & 427 & $16.3^{b}$ & 360 & $16.7^{\mathrm{ab}}$ & 481 & $19.8^{c}$ & $<0.001$ \\
\hline Without added sugar & 224 & $11.2^{\mathrm{ac}}$ & 233 & $8.9^{b}$ & 205 & $9.5^{\mathrm{ab}}$ & 298 & $12.2^{c}$ & $<0.001$ \\
\hline With added sugar & 164 & 8.2 & 194 & 7.4 & 155 & 7.2 & 183 & 7.5 & 0.67 \\
\hline Vegetables & 156 & 7.8 & 227 & 8.7 & 171 & 7.9 & 214 & 8.8 & 0.50 \\
\hline Other vegetables & 65 & 3.2 & 114 & 4.4 & 85 & 4.0 & 85 & 3.5 & 0.20 \\
\hline Red \& orange & 40 & 2.0 & 47 & 1.8 & 48 & 2.2 & 63 & 2.6 & 0.25 \\
\hline Potatoes & 34 & 1.7 & 40 & 1.5 & 29 & 1.4 & 54 & 2.2 & 0.12 \\
\hline Dark green & 17 & 0.9 & 26 & 1.0 & 9 & 0.4 & 12 & 0.5 & 0.05 \\
\hline Fruits & 144 & 7.2 & 177 & 6.8 & 150 & 7.0 & 160 & 6.6 & 0.88 \\
\hline Fruit & 94 & 4.7 & 126 & 4.8 & 115 & 5.3 & 107 & 4.4 & 0.53 \\
\hline $100 \%$ fruit juice & 50 & 2.5 & 51 & 2.0 & 35 & 1.6 & 53 & 2.2 & 0.23 \\
\hline Oils & 9 & 0.5 & 13 & 0.5 & 7 & 0.3 & 21 & 0.9 & 0.08 \\
\hline Dairy & 218 & 10.9 & 257 & 9.8 & 242 & 11.2 & 245 & 10.1 & 0.35 \\
\hline Cheese & 125 & 6.2 & 143 & 5.5 & 134 & 6.2 & 125 & 5.2 & 0.29 \\
\hline Milk-based desserts & 44 & 2.2 & 76 & 2.9 & 72 & 3.3 & 62 & 2.6 & 0.13 \\
\hline Fluid milk & 31 & 1.6 & 21 & 0.8 & 16 & 0.7 & 34 & 1.4 & 0.02 \\
\hline Yogurt & 18 & 0.9 & 17 & 0.7 & 20 & 0.9 & 24 & 1.0 & 0.55 \\
\hline Protein Foods & 525 & 26.2 & 657 & 25.1 & 557 & 25.9 & 560 & 23.1 & 0.66 \\
\hline Meat \& poultry & 391 & $19.5^{\mathrm{ab}}$ & 513 & $19.6^{\mathrm{ab}}$ & 457 & $21.2^{\mathrm{a}}$ & 433 & $17.8^{\mathrm{b}}$ & 0.04 \\
\hline Seafood & 97 & 4.8 & 85 & $3.2^{\mathrm{a}}$ & 50 & $2.3^{\mathrm{a}}$ & 70 & $2.9^{\mathrm{a}}$ & $<0.001$ \\
\hline Nuts and seeds & 20 & 1.0 & 30 & 1.1 & 23 & 1.1 & 36 & 1.5 & 0.45 \\
\hline Beans \& peas & 10 & 0.5 & 18 & 0.7 & 16 & 0.7 & 13 & 0.5 & 0.69 \\
\hline Eggs & 7 & 0.4 & 11 & 0.4 & 11 & 0.5 & 8 & 0.3 & 0.78 \\
\hline Water & 21 & 1.0 & 30 & 1.1 & 20 & 0.9 & 23 & 1.0 & 0.87 \\
\hline Empty calories & 300 & 15.0 & 408 & 15.6 & 376 & 17.5 & 388 & 16.0 & 0.15 \\
\hline Added sugars & 182 & 9.1 & 253 & 9.7 & 242 & 11.2 & 252 & 10.4 & 0.10 \\
\hline Solid fats & 118 & 5.9 & 155 & 5.9 & 134 & 6.2 & 136 & 5.6 & 0.85 \\
\hline Other $^{2}$ & 245 & $12.2^{\mathrm{a}}$ & 426 & $16.3^{b}$ & 271 & $12.6^{\mathrm{a}}$ & 335 & $13.8^{\mathrm{ab}}$ & $<0.001$ \\
\hline
\end{tabular}

${ }^{1}$ Values with the same superscript letters are not significantly different from each other.

${ }^{2}$ Includes combination foods; not enough detail available to separate out into groups.

examining either the front page only or the entire circular, and either in a national sample at a single time point or in a regional sample over a year. Ethan et al. reported the nutrition content of items on the first page of online sales circulars in the Bronx area [23]. They found that, at least on the front page, approximately $16 \%$ of advertisements were for vegetables or fruits, including $100 \%$ juice, compared to our findings of $15 \%$ and also reported that grain products accounted for $15 \%$ of ads compared to our results of $18 \%$. Again, using different methods and time periods, results are consistent, indicating that perhaps overall, the front page of circulars is representative of the content of the full advertisement. Regardless of the methodology, this important initial research consistently points to a lack of concordance between dietary guidance and food items advertised in sales circulars.

Compared to recommendations, purchases for fruits and vegetables are suboptimal while products high in solid fats and added sugars are excessive [25]. While there is little research linking food purchases to food consumption [38], a growing body of literature suggests that price reductions or provision of coupons and food vouchers can improve both purchases and dietary intake of healthy food [39]. Online coupons are becoming popular with retailers; however, current research indicates that online coupons are overwhelmingly for processed snack 
foods, not for healthier foods [40]. Many intervention efforts to promote the consumption of nutrient dense foods, especially fruits and vegetables, have turned to retail outlets. Economic incentives are often coupled with behavioral change strategies such as price manipulation, targeted coupons, in-store education, printed promotional materials, changes in product placement, and newspaper messages [41]. Other novel approaches include influencing purchasing by manipulating social meaning during shopping [42] and providing direct guidance for fruit and vegetable recommendations built into shopping carts [43]. Yet, to our knowledge, none have partnered with stores to target weekly circulars as a method of promoting price discounts of healthy, nutrient dense, foods. Relatively minor and inexpensive changes in content and placement of advertised items in circulars hold great potential to influence purchasing behavior and dietary intake to more closely align with recommendations.

The sales circulars were from a local grocery chain in the Midwest and may not reflect advertised products in other parts of the country. Other locations may also have a more pronounced seasonal variation in items advertised, especially vegetables and fruits, however, as our results were not dissimilar to other studies [22,23], they may be relevant to other parts of the country. Although coders worked in teams, coding was subjective and not all advertisements could be accurately classified, such as promotions where a variety of food items by one company were advertised together. We could not discriminate refined grains from whole grains as generally advertisements for ready-to-eat cereals and breads contained a variety of both whole- and non-whole grains. Because we counted each advertised item as it was displayed, we did not account for "buy one get one free" multiples. Although we did not distinguish between high- and low-fat meats or fried vs fresh fish, food items were categorized by subcategories of the major MyPlate food groups. Federal guidance recommends decreasing intake of solid fats and added sugars, but this is not reflected in the MyPlate icon. Strengths of the study include the use of foods in the entire circular, the use of a full years' worth of advertisements, and the comparison to federal dietary guidance. This novel approach adds to the sparse literature on grocery store sales circulars.

Stores use sales circulars to increase purchases by existing customers and to attract customers away from their usual grocery store by offering price discounts. However, if the sales circulars are not only interpreted as communicating purchasing deals but also function as intake guidance, then the relationship between sales circulars, purchasing behavior, and food consumption patterns needs to be investigated further.

Using a calendar year of supermarket sales circulars to ascertain information on the types of foods advertised helps us to understand consumer choices and can inform policy changes to promote healthier diets. Consumers indicate that weekly sales circulars are main factors in food purchasing decisions; thus, modification of the items advertised has the potential to significantly support people's efforts to eat healthier.

Reconfiguring sales circulars to promote healthier items may result in at least four possible outcomes: 1. No effect (i.e., new circulars are ignored); 2. A decrease in total sales and sales of healthier foods (i.e., consumer reactance to new circulars); 3. A decrease in total sales, but increase in healthier food sales (i.e., switching from less healthy food to more healthy food because of new circulars); 4. An increase in total sales and sales of healthier foods (i.e., keeping current purchasing patterns plus new healthy circular foods). Given what is known about price discounts and in-store marketing [24,43], we would expect outcomes \#3 or \#4. Currently, however, there is no empirical evidence examining the impact of systematic circular changes on purchases of healthier foods. Consequently, we expect this to be a fruitful area of future research regarding attempts to encourage healthier purchases. Increased focus on promoting fruits and vegetables in sales circulars may result in increased retail profits, through promotion of sales and simultaneous reduction in waste due to spoilage $[44,45]$ - a beneficial effect for the stores that would likely keep these foods consistently in weekly circulars.

\section{Conclusions}

The results of this study demonstrated that the food items advertised in weekly grocery circulars in this particular geographic location did not correspond to the current DGA recommendations. Nevertheless, health interventions via supermarket advertising are largely underexplored to date. If changes in advertisements were partnered with interventions sensitive to the needs of retail stakeholders, the goal to increase the proportion of Americans meeting national dietary guidance, thereby decreasing the risk of chronic disease, could be paralleled by increased profits for the participating retailers.

\section{Competing interests}

The authors declare that they have no competing interests.

\section{Authors' contributions}

$L J$ conceived the study. $\sqcup$, SK, CRP, and LDW developed the research questions and study design, interpreted data and drafted the manuscript. LKJ: performed statistical analysis, interpreted data and provided critical revisions of the manuscript: BSH and AJS: oversaw the study, collected data, performed analysis, interpreted data, and critically revised the manuscript. All authors approved the final version of this paper for publication.

\section{Acknowledgements}

This study was funded by the United States Department of Agricultural/ Agricultural Research Service, USDA 5450-51000-049-00D. The contents of this publication do not necessarily reflect the views or policies of the USDA or the Agricultural Research Service, nor does mention of trade names, commercial products, or organizations imply endorsement from the U.S. government. 


\section{Author details}

${ }^{1}$ United States Department of Agriculture, Agricultural Research Service, Grand Forks Human Nutrition Research Center, Grand Forks, ND 58203, USA 2Department of Marketing, New Mexico State University, Las Cruces, NM 88003, USA. ${ }^{3}$ Paso del Norte Institute for Healthy Living, 500 W. University Ave, El Paso, TX 79968, USA. ${ }^{4}$ Centre for Exercise, Nutrition, and Health Sciences, School of Policy Studies, 8 Priory Road, Bristol BS8 1TZ, USA.

Received: 22 May 2014 Accepted: 15 September 2014

Published: 23 September 2014

\section{References}

1. Food Marketing Institute: US grocery shopper trends 2012, executive summary. http://www.fmi.org/forms/store/ProductFormPublic/search? action=1\&Product_productNumber=2393.

2. Dawson J: Retailer activity in shaping food choice. Food Qual Pref 2013, 28:339-347.

3. Ellickson PB, Misra S: Supermarket pricing strategies. Market Sci 2008, 27:811-828

4. Tillotson J: Americans' food shopping in today's lousy economy. Nutr Today 2009, 44:167-169.

5. Tillotson J: Americans' food shopping in today's lousy economy (Part 2). Nutr Today 2009, 44:218-221.

6. Tillotson J: Americans' food shopping in today's lousy economy (Part 3). Nutr Today 2009, 44:265-268.

7. Tillotson J: Why does my food suddenly cost so much? Nutr Today 2009, 44:31-37.

8. Tillotson JE: The great recession's new reality reflects in consumer food shopping (part 2). Nutr Today 2010, 45:118-122.

9. U.S. Department of Agriculture ARS, Beltsville Human Nutrition Research Center, Food Surveys Research Group (Beltsville, MD), U.S. Department of Health and Human Services, Centers for Disease Control and Prevention, National Center for Health Statistics (Hyattsville, MD): What we eat in America, NHANES 2007-2008 documentation, codebook and frequencies: consumer behavior phone follow-up module. http://www.cdc.gov/nchs/ nhanes/nhanes2007-2008/cbqpfa_e.htm.

10. Food Marketing Institute: Supermarket facts, industry overview 2011 2012. http://www.fmi.org/research-resources/supermarket-facts.

11. Govindasamy R, Kumaraswamy A, Puduri V, Onyango B: An analysis of demographic characteristics of consumers who read grocery brochures regularly and those who are willing to switch supermarkets to buy advertised specials. J Food Prod Market 2007, 13:49-60.

12. Newspaper Association of America: Newspaper numbers. http://www.naa org/Trends-and-Numbers/Readership.aspx.

13. Burton S, Netemeyer R: Exposure to sales flyers and increased purchases in retail supermarkets. J Advert Res 1999, 39:7-14.

14. Bell DR, Chiang J, Padmanabhan V: The decomposition of promotional response: an empirical generalization. Market Sci 1999, 18:504-526.

15. Gilbert D, Jackaria N: The efficacy of sales promotions in UK supermarkets: a consumer view. Int J Retail Dist Manag 2002, 30:315-322.

16. Gijsbrechts $E$, Campo K, Goossens T: The impact of store flyers on store traffic and store sales: a geo-marketing approach. J Retail 2003, 79:1-16.

17. Macdonald JM: Demand, information, and competition: why do food prices fall at seasonal demand peaks? J Industr Econ 2000, 48:27-45.

18. Dong D, Leibtag E: Promoting fruit and vegetable consumption: are coupons more effective than pure price discounts? U.S. Department of agriculture, economic research service. Economic Res Report-96. http://www.ers.usda.gov/publications/err-economic-research-report/err96. aspx\#.U-uKNmP1vyU

19. Subar AF, Frey CM, Harlan LC, Kahle L: Differences in reported food frequency by season of questionnaire administration: the 1987 national health interview survey. Epidemiology 1994, 5:226-233.

20. Locke E, Coronado GD, Thompson B, Kuniyuki A: Seasonal variation in fruit and vegetable consumption in a rural agricultural community. J Am Diet Assoc 2009, 109:45-51.

21. Shahar DR, Froom P, Harari G, Yerushalmi N, Lubin F, Kristal-Boneh E: Changes in dietary intake account for seasonal changes in cardiovascular disease risk factors. Eur J Clin Nutr 2009, 53:395-400.

22. Martin-Biggers J, Yorkin M, Aljallad C, Cieierski C, Akhabue I, McKinley J, Hernandez K, Yablonsky C, Jackson R, Quick V, Byrd-Bredbenner C: What foods are US supermarkets promoting? A content analysis of supermarket sales circulars. Appetite 2012, 62C:160-165

23. Ethan D, Samuel $L$, Basch $C H$ : An analysis of bronx-based online grocery store circulars for nutritional content of food and beverage products. J Community Health 2013, 38:521-528.

24. Hawkes C: Sales promotions and food consumption. Nutr Rev 2009, 67:333-342.

25. Volpe RJ, Okrent A: Assessing the healthfulness of Consumer's grocery purchases. U.S. Department of agriculture, economic research service. Economic Info Bull-102. http://www.ers.usda.gov/publications/eib-economicinformation-bulletin/eib102.aspx\#.U-uJYWP1vyU.

26. Krebs-Smith SM, Guenther PM, Subar AF, Kirkpatrik SI, Dodd KW: Americans do not meet federal dietary recommendations. J Nutr 2010 140:1832-1838.

27. U.S. Department of Agriculture and U.S. Department of Health and Human Services: Dietary Guidelines for Americans, 2010. 7th edition. Washington, DC: US Government Printing Office; 2010.

28. U.S. Census Bureau: State and county QuickFacts. http://quickfacts.census. gov/gfd/states/38/38035.html.

29. Supermarket News: Top 50 small chains and independents report. http://supermarketnews.com/top-50-small-chains-independents-2010.

30. U.S. Department of Agriculture, Agricultural Research Service: USDA national nutrient database for standard reference, release 22. Nutrient Data Laboratory. http://www.ars.usda.gov/Services/docs.htm?docid=20960.

31. U.S. Department of Agriculture, Agricultural Research Service: Composition of foods: raw, processed, prepared. AH8. U.S. Department of Agriculture, Agricultural Research Service:1976-1992.

32. U.S. Department of Agriculture: ChooseMyPlate. http://www.choosemyplate.gov/.

33. Bowman SAFJ, Moshfegh A: MyPyramid Equivalents Database, 2.0 for USDA Survey Foods, 2003-2004, Food Surveys Research Group. Beltsville Human Nutrition Research Center, U.S. Department of Agriculture. Beltsville, MD: Agricultural Research Service. http://www.ars.usda.gov/Services/docs.htm? docid $=17565$.

34. SPSS: PASW Statistics for Windows. 180th edition. Chicago, I.L; 2009

35. Haberman SJ: The analysis of residuals in cross-classified tables. Biometrics 1973, 29:205-220.

36. SAS Institute I SAS: 9.2 nd edition. Cary, N.C: 2009.

37. Mancino L, Kuchler F, Leibtag E: Getting consumers to eat more whole-grains: the role of policy, information, and food manufacturers. Food Policy 2008, 33:489-496.

38. Eyeles $H$, Jiang $Y$, Ni Mhurchu C: Use of household supermarket sales data to estimate nutrient intakes: a comparison with repeat 24-hour dietary recalls. J Am Diet Assoc 2010, 110:106-110.

39. An R: Effectiveness of subsidies in promoting healthy food purchases and consumption: a review of field experiments. Public Health Nutr 2013 $16: 1215-1228$

40. Lopez A, Seligman HK: Online grocery store coupons and unhealthy foods, United States. Prev Chronic Dis 2014, 11:130211.

41. Escaron AL, Meinen AM, Nitzke SA, Martinez-Donate AP: Supermarket and grocery store-based interventions to promote healthful food choices and eating practices: a systematic review. Prev Chronic Dis 2013, 10:120156.

42. Payne CR, Niculescu M: Social meaning in supermarkets as a direct route to improve parents' fruit and vegetable purchases. Ag Res Econ Rev 2012 41:1-14.

43. Payne CR, Niculescu M, Just DR, Kelly MP: Shopper marketing nutrition interventions. Physiol Behav. in press.

44. McLaughlin EW: The dynamics of fresh fruit and vegetable pricing in the supermarket channel. Prev Med 2004, 39(Suppl 2):81-87.

45. Buzby JC, Wells HF, Axtman B, Mickey J: Supermarket loss estimates for fresh fruit, vegetables, meat, poultry, and seafood and their use in the ERS loss-adjusted food availability data. U.S. Department of agriculture, economic research service. Economic Info Bull-204. http://www.ers.usda. gov/media/183501/eib44.pdf.

doi:10.1186/1475-2891-13-95

Cite this article as: Jahns et al:: Foods advertised in US weekly

supermarket sales circulars over one year: a content analysis. Nutrition Journal 2014 13:95. 